doi.org/10.46291/ISPECIJSSHvol4iss2pp98-110

\title{
Hizmet Kalitesinin Müşteri Memnuniyeti Üzerine Etkisi: Bankacılık Sektörü Üzerine Bir Araştırma
}

\section{Sabeeha Azeez HASSAN}

Yard. Doç. Dr., Irak Üniversitesi, Kerkük, sabehaazez2013@yahoo.com

\begin{abstract}
Özet
Hizmet sektöründe faaliyet gösteren kurumlar için müşterilerin algıladıkları hizmet kalitesi çok önemlidir. Günümüzde, müşterilerin hizmet gereksinimlerini karşılamak için birçok alternatife sahip olması nedeniyle, işletmelerin hizmet kalitesine ve müşteri memnuniyetine daha fazla önem vermesi gerekmektedir. Bankacıllk sektörü, bu durumun en güçlü hissedildiği alanlar arasında yer almaktadır. Bankaların, mevcut müşterilerine daha iyi hizmet vermesi ve yeni müşteriler elde etmeleri için sürekli hizmet kalitelerini ve müşteri memnuniyetini ölçmesi ve buna göre önlem alması gerekmektedir. Bu çalışmada, Konya ilindeki farklı demografik özelliklere sahip 190 kişinin İş Bankasından aldıkları hizmet ile müşteri memnuniyetleri arasındaki ilişki ölçülmüş ve bu iki değişken arasında pozitif bir ilişki olduğu tespit edilmiştir.
\end{abstract}

Anahtar Kelimeler: Tüketici, Müşteri Memnuniyeti, Hizmet Kalitesi, Bankacılık Sektörü

\section{Effect of Service Quality on Customer Satisfaction: A Research on Banking Sector}

\begin{abstract}
The perceived service quality by customers is very important for institutions' operatation in the service sector. Today, businesses have many alternatives to meet customers' service needs. Therefore, businesses need to pay more attention to service quality and customer satisfaction. The banking sector is among the areas where this situation is felt most strongly. Banks need to constantly measure their service quality and customer satisfaction in order to serve their existing customers better and acquire new customers. Then, it is necessary to take measures according to these results. In this study, the relationship between the perceived service quality from Is Bankası and the customer satisfaction of 190 people with different demographic characteristics in Konya was measured and a positive relationship was found between these two variables.
\end{abstract}

Keywords: Consumer, Customer Satisfaction, Service Quality, Banking Sector 


\section{Giriş}

Son yıllarda işletmelerin verdiği hizmetin kalitesini ölçmek giderek önem kazanmaktadır. İşletmeler, müşteriler tarafından değerlendirilirken, algıladıkları hizmet kalitesi seviyesine dikkat etmektedir. İşletmeler de ellerindeki sadık müşterileri kaybetmemek ve yeni müşteriler kazanmak için sık sık müşterilerden geri bildirim almaktadırlar. Müşteri memnuniyeti, işletmelerin sunduğu hizmetin etkili olup olmadığının değerlendirilmesi konusunda kurumlara yardım etmektedir. Müşteri ilişkileri departmanları, sunulan hizmetin müşterileri memnun edip etmediğini ölçmekte ve bu sonuçlar doğrultusunda işletmeye yön vermektedir. Bu çalışmada, Konya ilindeki İş Bankasından hizmet alan müşterilerin firmanın verdiği hizmetlerden memnun olup olmadıkları ölçülmeye çalışılmıştır. İlk bölümde hizmet kalitesinin tanımına yer verilmiş, etkileri ve önemi açıklanmıştır. İkinci bölümde müşteri memnuniyeti üzerinde durulmuştur. Üçüncü ve son bölümde ise Konya ilinde gerçekleşen çalışmaya yer verilmiş, müşterilerin algıladıkları hizmet kalitesi ve müşteri memnuniyetlerinin ne oldukları analiz edilmiş ve yorumlanmıştır.

\section{Hizmet Kalitesi}

\subsection{Hizmetin Tanımı}

Hizmet kavramı, gerek soyut olması gerek geniş bir alana yayılması nedeniyle tanımlaması güçtür. Genel olarak kabul görmüş bir tanımı olmasa da maddi bir değeri olmayan ve tüketicilerin ihtiyaçlarını gideren bir ürün olarak ifade edilebilir. Hızla gelişen teknolojinin etkisi ile hizmet kalitesi ve bu kalitenin ölçülmesi konusuna verilen önem giderek artmaktadır. Hizmet kalitesi konusu üzerine yapılan çalışmalar da hızla artmaktadır. Kalitenin müşterilerin satın alma eğilimi üzerinde büyük bir etkisi olduğu bilinmektedir. Hizmetler de her ne kadar soyut özellikte olsalar da sahip oldukları kalite ile en az ürünler kadar rekabete konu olmaktadır. Hizmet sektöründe faaliyet gösteren işletme sayısının her geçen gün artması bu rekabet ortamını kızıştırmaktadır (Gümüşoğlu, 2007: 15).

Literatürde kabul edilen hizmet tanımlarından biri de Amerikan Pazarlama Birliği (AMA) tarafından yapılmıştır: Hizmet; soyut, aynı anda gerçekleşen ve tüketicilerin o esnada katılımıyla ortaya çıkan eylemlerdir. Boone ve Kurtz ise hizmet tanımına, "insanların ihtiyaçlarını gideren soyut işler” olarak ekleme yapmıştır (Boone ve Kurtz, 1995: 435).

Bir diğer tanımda, başka bir mal veya hizmete bağlı olmadan ihtiyaçların giderilmesini sağlayan soyut eylemler olarak ifade edilmektedir (Dinçer, 1997: 285). Bitner ve Zeithaml (2000: 3) tarafından yapılan hizmet tanımı ise, üretim süreci sonucunda somut bir çıtı olmayan ve üretildiği anda tüketime dönüşen; müşteriye uygunluk, zaman ve konfor açısından bir artı sağlayan bütün ekonomik eylemler olarak ifade edilmiştir. 


\subsection{Hizmet kalitesi}

Hizmetin kabul edilir bir tanımı olmadığından dolayı hizmet kalitesinin de araştırmacılar tarafından kabul edilmiş bir tanımı bulunmamaktadır. Hizmet alan kişilerin sosyal yapıları, ekonomik durumları ve toplumsal alışkanlıklarından ötürü hizmet kalitesi farklılık göstermektedir. Hizmet kalitesinin ölçülmesi için literatürde en çok kullanılan Serqual ölçeğini bulan Parasuraman, Zeithaml ve Berry (1985: 42) tarafindan hizmet kalitesi, beklenen hizmet ve algılanan hizmetin kıyaslanması şeklinde tanımlanmıştır. Diğer deyişle, verilen hizmetin tüketicinin beklentisini karşılayıp karşılayamadığının ölçüsü hizmet kalitesine karşılık gelmektedir. İşletme açısından kalite ise beklentileri karşılamaktır. Eğer beklenen kalite ile algılanan kalite arasındaki fark (-) yönde ise, tüketicilerin hizmeti olumsuz şekilde gördügünü gösterir ama aralarında $(+)$ yönde bir fark varsa tüketicilerin ürünlerini kaliteli bulduğunu belirtir (Değermen, 2006: 23).

Zengin ve Erdal (2000) tarafından gerçekleştirilen çalışmada, hizmet kalitesi ile ilgili aşağıdaki tanımlar sıralanmıştır:

- İşletme performanslarının hatasız olarak gerçekleştirilmesidir.

- Çalışan performanslarının hatasız olarak gerçekleştirmesidir.

- Sorunların ortadan kaldırılmasıdır.

- Güvenli, zamana uygun ve etkili performans gösterilmesidir.

- Müşterinin parası karşıllı̆ında aldığı değerdir.

- Güvenilir olmayan koşullar karşısında müşterinin korunmasıdır.

\subsection{Hizmet Kalitesini Oluşturan Faktörler, Etkiler ve Özellikleri}

Hizmet kalitesinin faktörleri arasında en çarpıcı olanı soyut olmasıdır. Bu özelliği nedeniyle hizmet, satıştan önce algılanamaz, görülemez, ölçülemez, biçimlendirilemez ve dokunulamaz. Hizmeti etkileyen faktör de heterojenliktir. Hizmetler birbirinden bağımsızdır ve farklı ihtiyaçlara göredir. Aynı hizmete ihtiyaç duyan farklı müşterilere verilmesi ve müşterilerin hizmeti alma konusunda farklı beklentilerinin olmasıdır. Üretim sektöründe kalite, ürün ortaya çıktıktan sonra da kazanılabilir. Fakat hizmet sektöründe hizmet soyut, depolanamaz ve o anda ortaya çıktığı için kalitenin sonradan kazanılması mümkün değildir. Bu özelliğe ise bütünlük denilmektedir. (Zincirkıran, 2016: 12).

Kotler 1997'de yaptığı çalışmada hizmet kalitesinin boyutlarını şu şekilde sıralamıştır:

- $\quad$ Erişilebilirlik

- $\quad$ İletişim

- $\quad$ Yetenek

- $\quad$ Nezaket

- $\quad$ İnanılırlık

- $\quad$ Güvenilirlik

Year 4/ 2020, Volume-4, Issue-2 | www.ispecjournal.org 
- $\quad$ Cevap vericilik

- Güvenlik

- $\quad$ Somut kısımların hizmet kalitesini doğru yansıtması

- $\quad$ Müşteriyi anlamak için çaba göstermek

Diğer bir araştırmacı Doyle (1994) ise hizmet boyutlarını şu şekilde sıralamıştır;

- Rahatlik

- $\quad$ Nezaket ve saygi

- $\quad$ Kredibilite

- $\quad$ Etkinlik

- $\quad$ Esneklik

- Dürüstlük

- $\quad$ Cevap verilebilirlik

- $\quad$ Güvenilirlik

- $\quad$ Emniyet

Parasuraman vd. (1985), algılanan hizmet kalitesinde etkili olan 10 faktör belirlemiştir:

Tablo1: Hizmet Kalitesinin Boyutlar1

\begin{tabular}{|c|c|c|}
\hline $\begin{array}{l}\text { Hizmet Kalitesi } \\
\text { Faktörleri }\end{array}$ & Tanım & $\begin{array}{c}\text { Müşterile rin Sorabileceği Soru } \\
\text { Ōrnekle ri }\end{array}$ \\
\hline İnanılırlık & $\begin{array}{l}\text { Hizmet üreticisinin güvenilirliği, } \\
\text { inandırıcılığı, dürüstluŭgüu }\end{array}$ & $\begin{array}{l}\text { İşletmenin iyi bir ũnũ var mı? } \\
\text { Verdiği sözleri yerine } \\
\text { getirebiliyor mu? }\end{array}$ \\
\hline Güvenlik & $\begin{array}{c}\text { Tehlike, risk ve şūpheden uzak } \\
\text { olmak }\end{array}$ & $\begin{array}{l}\text { Benimle ilgili bilgileri başka } \\
\text { yerlere iletiyor mu? }\end{array}$ \\
\hline Ulaşılabilirlik & $\begin{array}{c}\text { Yaklaşım ve kolay iletişim } \\
\text { kurabilme }\end{array}$ & $\begin{array}{l}\text { Bir problem olduğunda yetkili } \\
\text { kişiye kolaylıkla ulaşabiliyor } \\
\text { muyum? }\end{array}$ \\
\hline İletişim & $\begin{array}{l}\text { Müşterileri dinlemek ve } \\
\text { anlayacakları dilde onları } \\
\text { bilgilendirmek }\end{array}$ & $\begin{array}{l}\text { Bir șikayette bulunduğumda } \\
\text { yōnetim benimle ilgilenip } \\
\text { sorunumu anlıyor mu? }\end{array}$ \\
\hline $\begin{array}{l}\text { Mūşteriyi } \\
\text { anlamak }\end{array}$ & $\begin{array}{l}\text { Müşteriyi ve ihtiyaçlarını anlamak } \\
\text { için çaba sarf etmek }\end{array}$ & $\begin{array}{c}\text { Özel istek ve ihtiyaçlarıma cevap } \\
\text { verebilir mi? }\end{array}$ \\
\hline Fiziksel Unsurlar & $\begin{array}{c}\text { Fiziksel unsurların, kişilerin iletişim } \\
\text { araçlarının görünümü }\end{array}$ & $\begin{array}{l}\text { Fiziksel unsurlar temiz ve } \\
\text { düzgūn mü? }\end{array}$ \\
\hline Güvenilirlik & $\begin{array}{l}\text { Sõz verilen hizmeti dikkatli ve } \\
\text { güvenilir bir șekilde gerçekleștirme }\end{array}$ & $\begin{array}{l}\text { Hizmet ürünü için ödediğim para } \\
\text { fazla mi değil mi? }\end{array}$ \\
\hline $\begin{array}{l}\text { Karşıllık } \\
\text { verebilmek }\end{array}$ & $\begin{array}{l}\text { Mūşterilere yardımcı olma isteği ve } \\
\text { hizmetin zamanında sunulması }\end{array}$ & $\begin{array}{c}\text { Bir problemle karşılaş̧ı̆̆ımda } \\
\text { firma bu problemi kısa zamanda } \\
\text { çözebilecek mi? }\end{array}$ \\
\hline Yeterlik & $\begin{array}{l}\text { Hizmeti gerçekleştirebilmek için } \\
\text { gerekli bilgi ve beceri }\end{array}$ & $\begin{array}{l}\text { Hizmeti sunan kişi veya firma } \\
\text { konusunda uzman mı? }\end{array}$ \\
\hline Saygı & Saygilı olmak, kibarlık ve candanlık & $\begin{array}{c}\text { Hizmet personeli sorularımı } \\
\text { cevaplandırırken yeterince kibar } \\
\text { mı? }\end{array}$ \\
\hline
\end{tabular}

Kaynak: (Turaç, 2010: 7) 


\section{Müşteri Memnuniyeti}

\subsection{Müşteri ve Müşteri Memnuniyeti}

Müşteri kavramı, belirli bir markaya sahip ürünü, ticari ya da özel ihtiyaçlarını karşılamak için satın alan kişi ya da kuruluş şeklinde tanımlanmaktadır (Taşkın, 2000: 19). "Üretimde müşteri” ve "hizmet endüstrisinde müşteri” olmak üzere iki farklı biçimde değerlendirilmektedir. Üretimde müşteri; işletmenin ürettiği malı kullanacak kişi ya da kuruluşlardır. Hizmet endüstrisinde müşteri ise işletmenin sağladığı hizmetleri kullanacak olan kişi ya da kuruluştur (Bengisu, 2007: 270).

Müşteri memnuniyeti kavramı, müşterileri istek ve ihtiyaçlarına karşl1ık vermeyi hatta ötesine geçmeyi ifade eden bir kavramdır. Fiziksel ürünlerde müşteri memnuniyeti, söz konusu ürünün satın alınmasından sonraki kalite, performans vb. değerlendirilmelerdir. Hizmet açısından müşteri memnuniyeti ise hizmetin sunulması sırasında, müşterinin o hizmetten beklentilerine ne derece karşılık bulduğunun değerlendirilmesi ile ortaya çıkmaktadır. Temelde müşteri memnuniyeti, müşterilerin beklentileri ile algılarının karşılaştırılmasının sonucudur (Türk, 2005; 198).

Müşteri memnuniyeti işletmeler için büyük önem kazanmış bir olaydır. İşletmeler, müşteri memnuniyetinin geliştirilmesi için ilk olarak müşterilerin, kendi işletmelerini tercih etme nedenlerini ve işletmelerinden ne beklediklerini tespit etmek durumundadırlar. Müşteri satın alma davranışları da müşteri memnuniyeti için önemlidir. Bu davranış biçimlerinin tespit edilmesi ve buna göre stratejiler geliştirilmesi elzemdir. Bütün bu unsurların sonunda, müşterilerin beklentilerinin nasıl karşılayacaklarını belirlemek gerekmektedir (Ford, 2001: 39).

Müşteri memnuniyetinde müşteri tatmini önemli bir noktadır. Bu yüzden müşteri tatmini için işletmelerin aşağıdaki sekiz maddeye dikkat etmesi gerekmektedir: 
Şekil1: Müşteri Tatminin Etkileyen Faktörler

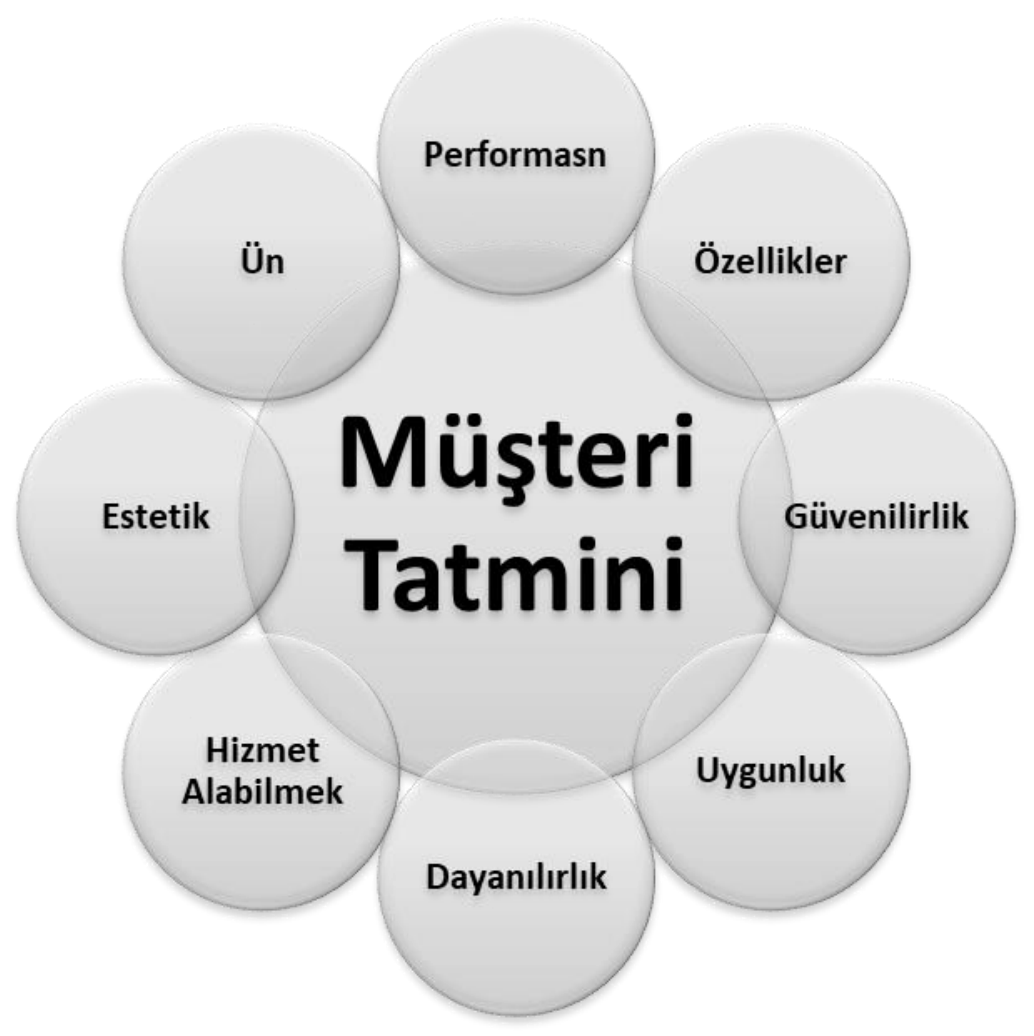

\subsection{Müşteri Memnuniyetini Etkileyen Faktörler}

Müşteri memnuniyetini etkileyen çok farklı değişkenler söz konusudur. Müşteri memnuniyetinin ölçülmesi için sadece müşterinin geçmiş deneyimlerini ölçmek yeterli olmayıp aynı zamanda memnuniyet ile birlikte ortaya çıkan yeni sonuçları da değerlendirmek gerekmektedir (Türkyılmaz ve Özkan, 2005: 75).

İşletme literatüründe müşteri memnuniyetini etkileyen faktörlerin genellikle işletmeyi ilgilendirenler ele alınmıştır (Tüzün ve Devrani, 2008: 14). Kristensen vd. (1997) göre, algılanan hizmet kalitesi müşteri memnuniyetini etkilemektedir. Clow vd. (1997) ve Eskilden (1999) ise işletme imajının müşteri memnuniyeti açısından öncelik olduğunu ifade etmektedir. Ayrıca, hizmet işletmelerinde müşteri memnuniyetini etki eden en önemli faktörün kalite olduğu bir diğer araştırmada ortaya konmuştur (Özgüven, 2008: 653). Fakat müşterilerin mal ve hizmetlerden elde ettiği memnuniyet, sadece ürün niteliklerine bağlı olmayıp; işletmenin imajının, satış elemanlarının tutumunun, tüketicinin kişiliğini, işletmenin profesyonellik anlayışının ve işlem hızının da müşteri memnuniyetini etkilediği ifade edilmektedir (Tan, 2004: 36). Bununla birlikte müşterilerin kültürel değerleri, demografik özellikleri, hizmetin sunulduğu mekânsal özellikler gibi çok sayıda değişken de müşteri memnuniyeti açısından önemli faktörlerdir (Özveren, 2010: 12). 


\section{Hizmet Kalitesinin Müşteri Memnuniyeti Üzerine Etkisi: Bankacılık Sektörü Üzerine Bir}

\section{Araştırma}

\subsection{Araştırmanın Konusu}

Araştırmanın konusu, Bankacılık sektöründe var olan hizmet kalitesinin, müşteri memnuniyeti üzerine etkisini incelemektir. Araştırmada veriler anket yoluyla elde edilmiş olup, SPSS 15 programı ile analiz edilip çıkan bulgular yorumlanmıştır.

\subsection{Araştırmanın Amacı}

$\mathrm{Bu}$ araştırmanın amacı, bankacılık sektöründen hizmet alan müşterilerin aldıkları hizmetlerin memnuniyetlerine nasıl etki ettiğini ortaya koymaktır. Bu iki değişken arasında ilişkiler ölçülmeye çalışılmış ve değerlendirilmiştir.

\subsection{Araştırmanın Önemi}

Bu araştırmanın önemi, bankacılık sektörünün hizmetlerinin, müşterilerin gözünde nasıl bir yere sahip olduğunu görmektir. Bankaların verdikleri hizmetlerin nasıl değerlendirildiği, algılandığı ve bunun memnuniyet derecelerini ölçüp aralarındaki ilişkiyi tanımlamaktır.

\subsection{Araştırma Yöntemi}

Bankacılık sektörü günümüzde hemen her kesimin kullandığı bir sektör olarak bilinmektedir. İnsan hayatını kolaylaştıran ve farklı demografik özelliklerde olan kullanıcıların bulunduğu bu ortamlar farklı görüşler barındırmaktadır. Bu yüzden araştırmanın ana kütlesi bu farklılık nedeniyle İş Bankası ile çalışan müşterilerdir. Ana kütlenin büyük olması nedeniyle, Konya ili baz alınarak 200 kişiye kolayda örneklem yolu ile anket uygulanmıştır. Yapılan 200 anketten 10 tanesi geçersiz cevaplar yüzünden uygulamadan çıkartılmış ve 190 anket üzerinden analizler yapılmıştır.

Araştırmada test edilecek hipotezler şunlardır;

$\mathbf{H}_{\mathbf{0}}$ :Hizmet kalitesi ve müşteri memnuniyeti arasında pozitif bir ilişki vardır.

$\mathbf{H}_{1}$ : Hizmet kalitesi ve müşteri memnuniyeti arasında pozitif bir ilişki yoktur.

$\mathbf{H}_{2}$ : Genel müşteri memnuniyeti cinsiyete göre değişiyor mu?

\subsection{Verilerin Toplanması}

Araştırmanın veri toplama yöntemi anket çalışmasıdır. Anket sorularının hazırlanmasında hizmet kalitesi ve müşteri memnuniyeti literatürü taranarak tespit edilen ölçeklerden faydalanılmıştır. 3 bölümden oluşan anket çalışmasının ilk bölümündeki hizmet kalitesi ile ilgili sorular için Parasuraman'ın (1988) oluşturduğu Serqual ölçeği; ikinci bölümdeki müşteri memnuniyeti ile ilgili 
sorular için ise Oliver (1980) tarafından geliştirilen müşteri memnuniyet ölçeği kullanılmıştır. Anketin üçüncü bölümünde demografik özellikleri ölçen sorular bulunmaktadır.

\subsection{Araştırmanın Bulguları}

Yapılan anketler sonucu veriler SPSS 15 programı ile analiz edilerek yorumlanmıştır. Demografik sorulara ilişkin frekans analizi sonuçları aşağıdaki tabloda gösterilmiştir.

Tablo2:Cinsiyet, Yaş, Medeni Hal Frekans Tablosu

\begin{tabular}{|c|c|c|}
\hline CiNSIYYET & Frekans & Yüzde \\
\hline KADIN & 82 & 43,2 \\
\hline ERKEK & 108 & 56,8 \\
\hline Toplam & 190 & 100,0 \\
\hline YAŞ & & \\
\hline $18-27$ & 170 & 89,5 \\
\hline $28-37$ & 16 & 8,4 \\
\hline $38-47$ & 2 & 1,1 \\
\hline 68 VE USTU & 2 & 1,1 \\
\hline Toplam & 190 & 100,0 \\
\hline $\begin{array}{c}\text { MEDİNi் } \\
\text { HAL }\end{array}$ & & \\
\hline Evli & 30 & 15,8 \\
\hline Bekâr & 160 & 84,2 \\
\hline Toplam & 190 & 100,0 \\
\hline
\end{tabular}

Ankete katılanların \%57'sinin erkek; \%43'lük kısmını da kadınların oluşturduğu bu çalışmada katılımcıların \%89'luk bölümünün 18-27 yaş aralığında olduğu görülmüştür. Bu yüzden çıkan sonuçların genç denilebilecek bir nüfusun cevabı olarak sayılması mümkündür. Katılımcıların \%84'lük kısmının da bekâr olduğu görülmektedir.

Tablo3: Eğitim, Gelir, İş Cep Frekans Tablosu

\begin{tabular}{|l|c|c|}
\hline Ĕgitim Durumu & Frekans & Yüzde \\
\hline İlkokul & 8 & 4,2 \\
\hline Lise ve dengi & 16 & 8,4 \\
\hline Lisans & 154 & 81,1 \\
\hline Lisansüstï & 12 & 6,3 \\
\hline Toplam & 190 & 100,0 \\
\hline Gelir Durumu & & \\
\hline $0-1500$ & 156 & 82,1 \\
\hline $1501-2600$ & 16 & 8,4 \\
\hline $2601-3900$ & 4 & 2,1 \\
\hline $3901-5200$ & 4 & 2,1 \\
\hline $5201-6500$ & 6 & 3,2 \\
\hline
\end{tabular}




\begin{tabular}{|l|c|c|}
\hline 6501 ve üstü & 4 & 2,1 \\
\hline Toplam & 190 & 100,0 \\
\hline $\begin{array}{l}\text { İş Cep } \\
\text { Kullanımı }\end{array}$ & & \\
\hline EVET & 66 & 34,7 \\
\hline HAYIR & 124 & 65,3 \\
\hline Toplam & 190 & 100,0 \\
\hline
\end{tabular}

Katılımcıların \%81'lik bölümünün eğitim durumlarının lisans mezunu olduğu görülmektedir. Gelir durumlarına bakıldığında ise \%82'lik kısmın 0-1500Tl arası bir gelire sahip oldukları görülmüştür. Anket çalışmasına katılan kişilere İş Bankasının mobil uygulaması olan “iş CEP”i kullanıp kullanmadıkları sorulduğunda \%65'lik bölümün kullanmadıkları anlaşılmış, geriye kalan \%35'lik bölüm ise aktif olarak bu uygulamayı kullandıklarını söylemişlerdir.

Tablo4:Meslek Frekans Tablosu

\begin{tabular}{|l|l|l|}
\hline Mesleğiniz & Frekans & Yüzde \\
\hline Özel sektörde isçi & 10 & 5,3 \\
\hline Özel sektörde memur & 4 & 2,1 \\
\hline $\begin{array}{l}\text { Kamu sektöründe } \\
\text { memur }\end{array}$ & 2 & 1,1 \\
\hline $\begin{array}{l}\text { Uzmanlık gerektiren } \\
\text { meslek sahibi }\end{array}$ & 2 & 1,1 \\
\hline Üst düzey yönetici & 2 & 1,1 \\
\hline $\begin{array}{l}\text { Ticari serbest meslek } \\
\text { sahibi }\end{array}$ & 2 & 1,1 \\
\hline Ev hanımı & 4 & 2,1 \\
\hline Sporcu, sanatçı & 4 & 2,1 \\
\hline Hayvancilık ve çiftçilik & 2 & 1,1 \\
\hline Öğrenci & 146 & 76,8 \\
\hline İșsiz fakat gelir sahibi & 4 & 2,1 \\
\hline İşsiz & 8 & 4,2 \\
\hline Toplam & 190 & 100,0 \\
\hline
\end{tabular}

Anket çalışmasını dolduran katılımcıların meslekleri ile ilgili soruya verdikleri cevaplara bakıldığında katılımcıların \%76'sının öğrenci olduğu tespit edilmiş, \%5'inin işçi ve \%4'ünün ise işsiz oldukları görülmüştür.

Anket çalışmasında uygulanan hizmet kalitesi ve müşteri memnuniyeti ölçeklerine güvenilirlik testi uygulanmıştır. Çıkan sonuçlara göre hizmet kalitesi ölçeğinde Crombach alfa değeri $\alpha=0,928$ çıkmıştır. Diğer ölçek olan müşteri memnuniyeti ölçeğinde ise $\alpha=0,845$ çıkmıştır. 
Hipotezlerin analizini gerçekleştirmek adına korelasyon analizinin yapılabilmesi için hizmet kalitesi ve müşseri memnuniyeti ölçeklerine Kolmogorov- Smirnov normallik testi uygulanarak ölçekler arasında normal dağılım olup olmadığına bakılmıştır.

Tablo5: Normallik Testi

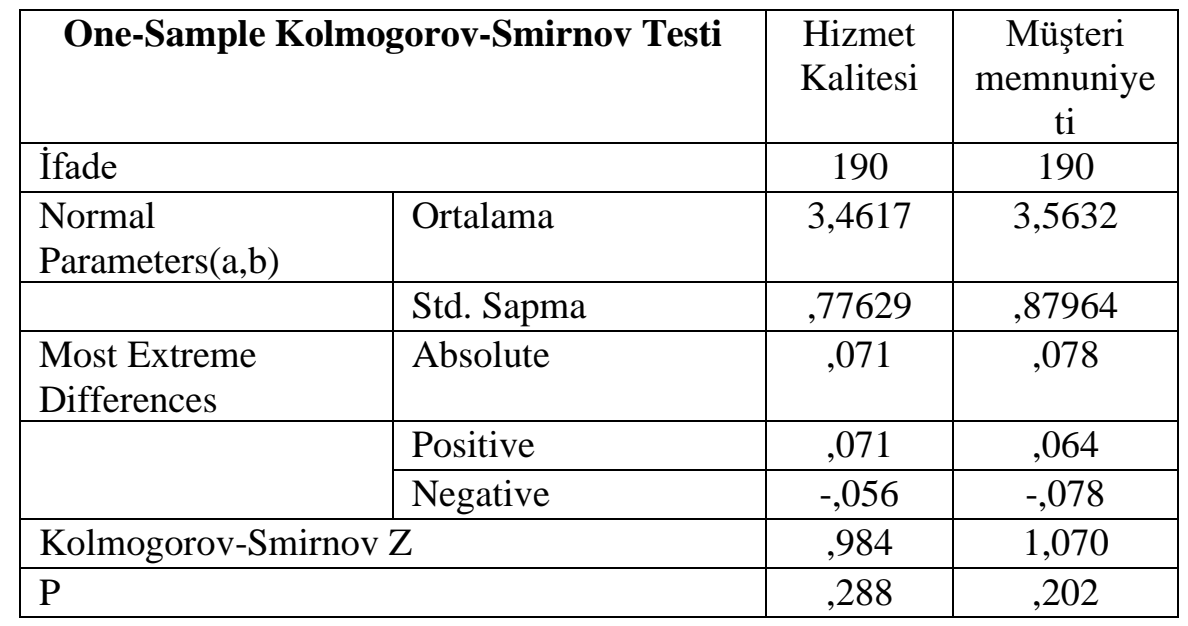

Çıkan sonuçlara bakıldığında P değerinin 0,05 'den büyük olduğu iki ölçek içinde görülmüştür. Hizmet kalitesi ve müşteri memnuniyeti ölçekleri normal dağılım gösterdikleri için $\mathrm{H}_{0}$ ve $\mathrm{H}_{1}$ hipotezleri için yapılacak olan korelasyon analizinde olumsuz bir durum bulunmamıştır. Bu sonuçlar doğrultusunda Pearson korelasyon analizi yapılmış ve sonuçlar yorumlanmıştır.

Tablo6: Korelasyon Tablosu

\begin{tabular}{|l|l|c|c|}
\hline \multicolumn{2}{|c|}{ Korelasyon } & $\begin{array}{c}\text { Hizmet } \\
\text { kalitesi }\end{array}$ & $\begin{array}{c}\text { Müşteri } \\
\text { memnuniyeti }\end{array}$ \\
\hline $\begin{array}{l}\text { Hizmet } \\
\text { kalitesi }\end{array}$ & $\begin{array}{l}\text { Pearson } \\
\text { Correlation }\end{array}$ & 1 &, $652(* *)$ \\
\hline & P & &, 000 \\
\hline & İfade & 190 & 190 \\
\hline $\begin{array}{l}\text { Müşteri } \\
\text { Memnuniyet } \\
\text { i }\end{array}$ & $\begin{array}{l}\text { Pearson } \\
\text { Correlation }\end{array}$ &, $652\left(^{*}\right)$ & 1 \\
\hline & P &, 000 & \\
\hline & İfade & 190 & 190 \\
\hline
\end{tabular}

Yapılan analizin ardından Pearson Korelasyonu 0,652 çıkmış ve iki ölçek arasında güçlü bir ilişki tespit edilmiştir. " $\mathrm{H}_{0}$ : Hizmet kalitesi ve müşteri memnuniyeti arasında pozitif bir ilişki vardır." hipotezi kabul edilmiştir. Çalışmanın diğer hipotezi olan " $\mathrm{H}_{1}$ : Hizmet kalitesi ve müşteri memnuniyeti arasında pozitif bir ilişki yoktur." hipotezi ise kabul edilmemiştir. 
Tablo7: T-Testi Tablosu

\begin{tabular}{|l|l|l|l|l|l|}
\hline Cinsiyetiniz & İfade & Ortalama & Std. Sapma & $\mathrm{T}$ & $\mathrm{P}$ \\
\hline KADIN & 82 & 3,5163 &, 77496 & -658 &, 031 \\
\hline ERKEK & 108 & 3,5988 &, 95350 & & \\
\hline
\end{tabular}

Son hipotez için yapılan t-testinde P değerinin 0,05 değerinden küçük olmasından dolayı genel müşteri memnuniyetinin cinsiyetlere göre değişmediği görülmektedir. Çıkan sonuçlara göre " $\mathrm{H}_{2}$ : Genel müşteri memnuniyeti cinsiyete göre değişiyor mu?" hipotezinin cevabı değişmediği yönündedir.

\section{Sonuç ve Öneriler}

İşletmeler, müşterilerinin memnuiyetini kazanmak ve bunu devam ettirmek için verdikleri hizmetin kalitesini üst seviyede tutmaya çalışmaları gerekmektedir. İşletmelerin bunu sağlayabilmesi için müşterilerini iyi tanıması gerekir. Ayrıca teknolojik gelişmeleri ve toplumsal değişimleri yakından takip etmeleri gerekmektedir. Bu sayede işletmeler farkındalık yaratma konusunda piyasada üstünlük sağlayabileceklerdir.

Tüm sektörlerde olduğu gibi bankacılık sektörü de hizmet kalitesine ve müşteri memnuniyetine önem vermektedir. Rekabet üstünlüğü sağlaması için hizmetlerinin müşterilerce nasıl algılandığını ölçmesi gerekir. Bu çalışmaya katılan katılımcıların yüzdesel oranları birbirine yakın olduğu için çıkan sonuçların her iki cinsiyet içinde geçerli olduğu görülmektedir. Hipotezler arasında yer alan cinsiyetlerin müşteri memnuniyetinde farklılık gösterip göstermediği sorusunun negatif çıkması da bu sonucu onaylamaktadır. Bankacılık sektöründe bankalar varlığını koruması için var olan teknolojiyi iyi bilmeli ve kendilerini bu yönde geliştirmelidir. Bunun için sektördeki yeni bilgileri iyi analiz etmeleri ve takip etmeleri gerekmektedir.

Sonuçlara bakıldığında Konya'da İş bankasının müşteri memnuniyetine önem verdiği görülmektedir. Çalışanların iyi eğitimli olduğu, giyimlerine önem verdiği, bankanın dış görünüşünün ve verdikleri hizmetin kullandıkları teknolojiyle uyumlu olduğu görülmüştür. İş bankasının verdiği hizmetlerden memnun kalan katılımcılar müşterilere gösterilen ilgiden hoşnut olduklarını söylemişlerdir.

Müşterilerin beklentilerini doğru anlamak, bu beklentilere ve sorunlara hızlı, kolay ve zamanında cevap vermek gibi faktörlerin önemli olduğu gözlemlenmiştir. Müşteri memnuniyetinin önemli bir konusu olan bu faktörler, işletmeler tarafından unutulmaması gereken en önemli faktörlerdir. Genel olarak bakıldığında ise İş bankasının mobil şube olarak kullandığı "İş cep Mobil” uygulamasının katılımcılara verdikleri cevaplara göre fazla kullanılmadığı görülmüştür. İş bankasının masraflarını azaltmak ve müşterilerine daha iyi hizmet vermek için bu uygulamayı iyi tanıtması ve kullanımını kolaylaştırması gerektiği sonucuna ulaşılmıştır. 


\section{KAYNAKÇA}

Bengisu, M. (2007). Yüksek eğitimde toplam kalite yönetimi. Journal of Yasar University. 2(7), 739-749.

Bitner M. ve Zeithaml, V. A. (2010). Services marketing: Integrating customer focus across the firm. New York: McGraw Hill.

Boone L. ve Kurtz, D. (1995). Contemporary Marketing. Chicago: Dryden Press.

Clow, K. E., Kurtz, D. L., Ozment, J. ve Ong, B. S. (1997). The antecedents of consumer expectation of services: Empirical study across four industries. The Journal of Services Marketing. 11(4), 230-248.

https://doi.org/10.1108/08876049710171704

Değermen, H. A. (2006). Hizmet ürünlerinde kalite, müşteri tatmini ve sadakati. İstanbul: Türkmen Kitabevi.

Dinçer Ö. (1997). Stratejik yönetim ve işletme politikası. İstanbul: Beta Basım Yayım.

Doyle, P. (1994). Marketing management and strategy. New York: Prentice Hall.

Eskilden, J. (1999). Benchmarking student satisfaction in higher education based on the ecsi methodology. TQM for Higher Education Institutions Conference: Higher Education Institutions and The Issue of Total Quality. 30-31 Ağustos 1999, Verona.

Ford, R. C., Heaton, C. P., ve Brown, S. W. ( 2001). Delivering excellent services: lessons from the best firms. California Management Review. 44(1), 39-56. https://doi.org/10.2307/41166110

Gümüşoğlu, Ş. (2007). Hizmet kalitesi: Kavramlar, yaklaşımlar ve uygulamalar. Ankara: Detay Yayıncılık.

Kotler, P. (1997). Marketing Management, analysis, planning, implementation and control. (9. Bask1). New Jersey: Prentice-Hall.

Kristensen, K. (1999). Measurement impact of buying behavior on customer satisfaction.

$\begin{array}{llll}\text { Total Quality } & \text { Management. }\end{array}$ https://doi.org/10.1080/0954412997587

Oliver, R. L. (1980). A cognitive model of the antecedents and consequences of satisfaction decisions. Journal of Marketing Research. 17(4), 460-469. https://doi.org/10.1177/002224378001700405

Özgüven, N. (2008). Hizmet pazarlamasında müşteri memnuniyeti ve ulaştırma sektörü üzerinde bir uygulama. Ege Akademik Bakış Dergisi. 8(2), 651-682. https://doi.org/10.21121/eab.2015221927 
Özveren, Y. S. (2010). Müşteri Memnuniyeti ve Hizmet Kalitesi İlişkileri: Mersin İlindeki 4 ve 5 yıldızlı Oteller Örneği. Yayımlanmamış Yüksek Lisans Tezi, Mersin Üniversitesi.

Parasuraman, A., Zeithaml, V. A. ve Berry, L. B. (1985). A conceptual model of service quality and its implications for future research. The Journal of Marketing. 49(4), 41-50. https://doi.org/10.1177/002224298504900403

Parasuraman, A., Zeithaml, V. A. ve Berry, L. L. (1988). SERVQUAL: a multiple-item scale for measuring consumer perceptions of service quality. Journal of Retailing. 64 (1). $12-40$

Tan, A. (2004). Dinlenme tesislerinde hizmet pazarlaması ve müşteri tatmini. Pazarlama Dünyas1. Say1 5.

Taşkın, E. (2000). Müşteri ilişkileri eğitimi. (2. Baskı). İstanbul: Papatya Yayıncılık.

Turaç, Y. (2010). Hizmet kalitesi ölçümünde almaşık teknikler. Yayımlanmamış Yüksek Lisans Tezi. Gazi Üniversitesi, Ankara.

Türkyılmaz, A. ve Özkan, C. (2005). Ulusal müşteri memnuniyet indeksleri. Kalder Forum Dergisi. 16, 73-77.

Türk, K. (2007). Hizmet isletmelerinde etkin maliyet tespiti ve bir uygulama örneği. Yayımlanmamış Yüksek Lisans Tezi. Gazi Üniversitesi, Ankara.

Tüzün, İ. K. ve Devrani, T. K. (2008). Müşteri memnuniyeti ve müşteri-çalışan etkileşimi üzerine bir araştırma. Eskişehir Osmangazi Üniversitesi İktisadi ve İdari Bilimler Fakültesi Dergisi. 3 (2), 13-24.

Zengin, E. ve Erdal, A. (2000), "Hizmet sektöründe toplam kalite yönetimi", Journal of Qafqaz University. 3(1), 43-56.

Zincirkıran, M. (2016). Örgütsel sağlık, hizmet kalitesi ve sağlıkta hizmet kalitesi üzerine etkileri. Yayımlanmamış Yüksek lisans Tezi. Beykent Üniversitesi, İstanbul. 